\title{
Genetic differences in the IGF-I gene among inbred strains of mice with different serum IGF-I levels
}

\author{
K lida, C J Rosen ${ }^{1}$, C Ackert-Bicknell ${ }^{1}$ and $M$ O Thorner \\ Division of Endocrinology and Metabolism, Department of Internal Medicine, University of Virginia, Charlottesville, Virginia, USA \\ ${ }^{1}$ The Jackson Laboratory, Bar Harbor, Maine, USA \\ (Requests for offprints should be addressed to M O Thorner, Box 800466, Department of Internal Medicine, University of Virginia, Charlottesville, Virginia \\ 22908, USA; Email: mot@virginia.edu)
}

\begin{abstract}
There is significant heterogeneity in serum IGF-I concentrations among normal healthy individuals across all ages and among inbred strains of mice. $\mathrm{C} 3 \mathrm{H} / \mathrm{HeJ}(\mathrm{C} 3 \mathrm{H})$ mice have 30\% higher serum IGF-I concentrations over a lifetime than C57BL/6J (B6), even though body size and length are identical. The underlying mechanism for this disparity remains unknown although several possibilities exist including altered $\mathrm{GH}$ secretion, resistance to $\mathrm{GH}$ action, or impaired IGF-I secretion from the liver or peripheral tissues. To study this further, we evaluated mRNA levels of pituitary GH, and of IGF-I, GH receptor (GHR) and acid-labile subunit (ALS) in liver and skeletal muscle of male $\mathrm{C} 3 \mathrm{H}$ and $\mathrm{B} 6$ strains. mRNA levels of hepatic IGF-I paralleled serum IGF-I levels, whereas pituitary GH mRNA expression was significantly lower in
\end{abstract}

$\mathrm{C} 3 \mathrm{H}$ than B6. In addition, reduced hepatic mRNA levels of ALS and GHR in B6 suggests hepatic GH resistance in B6. In contrast, mRNA levels of IGF-I and GHR in skeletal muscle were not different between $\mathrm{B} 6$ and $\mathrm{C} 3 \mathrm{H}$. There was a single sequence repeat polymorphism (SSR) in the promoter region of both GHR and IGF-I genes in mice; the SSR in the IGF-I gene was significantly different between the two strains. The SSR in the IGF-I gene corresponds to the E2F binding site, which is critical for regulating IGF-I gene expression. These results suggest that the SSR in the promoter region of the IGF-I gene may be partially responsible for differences in serum IGF-I levels between $\mathrm{B} 6$ and $\mathrm{C} 3 \mathrm{H}$ strains.

Journal of Endocrinology (2005) 186, 481-489

\section{Introduction}

Insulin-like growth factor-I (IGF-I) is a ubiquitous peptide that has multiple physiological functions acting through endocrine, paracrine and autocrine pathways (D'Ercole et al. 1984, Stewart \& Rotwein 1996). Several lines of evidence suggest that genetic determinants may regulate human serum IGF-I concentrations. Studies in healthy twin children indicated marked genetic influences on serum IGF-I levels (Kao et al. 1994, Harrela et al. 1996). There are also epidemiological reports that serum IGF-I levels vary greatly even between normal individuals and between ethnic groups regardless of their serum growth hormone (GH) levels (Platz et al. 1999). Recent evidence suggests that the serum IGF-I phenotype is a complex heritable trait with multiple genetic determinants, some of which may be GH-independent (Rosen et al. 2000). The association of serum IGF-I concentrations with glucose tolerance (Sandhu et al. 2002), bone mineral density (BMD) (Langlois et al. 1998) or risk of cancers (Giovannucci 1999) makes identification of genetic determinants of serum IGF-I levels important.
In humans, there are several cases of inherited syndromes with low serum IGF-I levels, which include congenital GH deficiency (Procter et al. 1998), bioinactive GH (Takahashi et al. 1996, 1997), mutations of the protein-coding region of the $\mathrm{GH}$ receptor (GHR) gene (Laron 2004), a mutation of signal transducer and activator of transcription (STAT) 5b protein (Kofoed et al. 2003), IGF-I gene deletion (Woods et al. 1996), and inactivation of the acid-labile subunit (ALS) gene (Domene et al. 2004). These cases suggest that genes encoding the molecules involved in the GH-IGF-I axis play a critical role in determining serum IGF-I levels. Furthermore, polymorphisms in the promoter region of the human IGF-I gene are associated with variation of serum IGF-I levels (Rosen et al. 1998).

In mice, serum IGF-I levels vary considerably between strains. $\mathrm{C} 3 \mathrm{H} / \mathrm{HeJ}$ (hereafter $\mathrm{C} 3 \mathrm{H}$ ) mice have 30\% higher serum IGF-I concentrations than C57BL/6J (hereafter B6) mice although there are no differences in body length and weight between the two strains (Rosen et al. 1997). C3H mice with higher serum IGF-I levels have increased BMD compared with B6. B6 mice have higher glycosylated 
hemoglobin levels (Kaku et al. 1989) and demonstrated poor glucose tolerance with a lower insulin response to i.p. glucose administration compared with $\mathrm{C} 3 \mathrm{H}$ (Kayo et al. 2000). B6 mice are also susceptible to atherosclerosis, whereas C3H are resistant (Ishida et al. 1991, Shi et al. 2000). On the other hand, primary cultured hepatocytes from $\mathrm{C} 3 \mathrm{H}$ are susceptible to hepatocarcinogenesis whereas those from B6 are resistant (Yoshie et al. 1998). Although these two inbred mice have been extensively studied as models of genetic influences on metabolism of glucose, lipid and bone or carcinogenesis, it is still unknown whether genetic differences between strains may exist in the genes involved in the GH-IGF-I axis. We hypothesized that characteristics of B6 might be explained in part by reduced GH action: either low GH synthesis in the pituitary gland or GH resistance in peripheral tissues. Alternatively, a $\mathrm{GH}$-independent factor such as alteration of IGF-I gene per se may account for low serum IGF-I levels in B6.

In this study, we first characterized mRNA expression of pituitary $\mathrm{GH}$ in $\mathrm{B} 6$ and $\mathrm{C} 3 \mathrm{H}$ using quantitative real-time RT-PCR to elucidate whether low GH synthesis is responsible for low serum IGF-I levels in B6. We then examined mRNA levels of hepatic IGF-I, ALS and GHR to clarify whether B6 is characterized by reduced hepatic GH action. We also quantified IGF-I as well as GHR mRNA levels in skeletal muscle to elucidate the tissue-specificity in $\mathrm{GH}$ action between the two strains. Finally, we examined sequence differences in the promoter and protein-coding region of GHR as well as IGF-I genes between $\mathrm{B} 6$ and $\mathrm{C} 3 \mathrm{H}$ mice and identified single sequence repeat polymorphisms (SSRs).

\section{Materials and Methods}

\section{Animals}

Male C57BL/6J (B6) and $\mathrm{C} 3 \mathrm{H} / \mathrm{HeJ}(\mathrm{C} 3 \mathrm{H})$ inbred mice of 8 weeks of age were used in this experiment. The mouse colonies were maintained and housed in an animal care facility at the Jackson Laboratory (Bar Harbor, ME, USA). They were maintained under conditions of $14 \mathrm{~h}$ light: $10 \mathrm{~h}$ darkness and an ambient temperature of $20 \cdot 2{ }^{\circ} \mathrm{C}$. Water (acidified with $\mathrm{HCl}, \mathrm{pH} 2 \cdot 8-3 \cdot 2$ ) and an autoclaved NIH31 pellet diet (18\% protein, $6 \%$ fat, $1 \cdot 27 \%$ $\mathrm{Ca}, 0.92 \% \mathrm{P}$, trace mineral and vitamin fortified; Purina, Madison, WI, USA) were freely available. The body weights of $\mathrm{B} 6$ and $\mathrm{C} 3 \mathrm{H}$ were not different, as described previously (Rosen et al. 1997). We previously reported that serum IGF-I concentrations as measured by a specific RIA were 30\% higher in $\mathrm{C} 3 \mathrm{H}$ than $\mathrm{B} 6$ at 4 and 8 weeks in both male and female mice (Rosen et al. 1997). The mice were killed at 8 weeks and pituitary gland, liver, skeletal muscle (quadriceps femoris) from $\mathrm{B} 6$ and $\mathrm{C} 3 \mathrm{H}$ $(n=10 /$ group $)$ were collected and flash-frozen in liquid nitrogen and then stored at $-80{ }^{\circ} \mathrm{C}$ for subsequent mRNA analysis. Use of mice in this research project was reviewed and approved by the Institutional Animal Care and Use Committee of the Jackson Laboratory.

\section{Serum IGF-I measurements}

Serum IGF-I in mouse sera was measured by RIA after removal of IGF-binding proteins as described previously (Rosen et al. 1997).

\section{Total RNA preparations}

The RNA extraction was performed using Tri Reagent (Molecular Research Center, Inc., Cincinnati, OH, USA) followed by an RNeasy Mini Kit (Qiagen, Inc., Valencia, CA, USA) with DNase treatment according to the manufacturers' instructions. The quantity of extracted total RNA was determined using the RiboGreen RNA Quantitation Kit (Molecular Probes, Eugene, OR, USA) with a Genios multi-detection reader (Phenix Research Product, Hayward, CA, USA).

\section{Real-time RT-PCR}

Primers for quantification of murine GH, GHR, IGF-I and ALS mRNAs are listed in Table 1. The reaction of RT-PCR was described previously (Iida et al. 2004a). Briefly, $1 \mu \mathrm{g}$ total RNA from the liver and skeletal muscle and $100 \mathrm{ng}$ total RNA from the pituitary gland were reverse transcribed in a total volume of $10 \mu \mathrm{l}$ using the iScript cDNA Synthesis Kit (Bio Rad Laboratories, Hercules, CA, USA) according to the manufacturer's instruction. A 1:20 dilution of the resultant cDNA was prepared and $4 \mu \mathrm{l}$ of this template were used in the real-time PCR protocol. The iCycler iQ Real-Time PCR detection system (Bio-Rad Laboratories) was used for sample cDNA quantification. The PCR was performed in a total volume of $20 \mu \mathrm{l}$ and SYBR Green I (Molecular Probes) was used for detection of PCR products.

\section{Quantification}

We constructed the plasmid including the PCR product of the target gene and the DNA concentration of constructed plasmid was determined as described previously (Iida et al. 2004a). These plasmids were used for standards of quantification. A standard curve was generated by amplifying serial dilutions of a known quantity of plasmid DNA. The standards and cDNA samples were then co-amplified in the same reaction plate. The standard curve displayed a linear relationship between cycle threshold $(\mathrm{Ct})$ values and the logarithm of input plasmid copy number. The amount of product in a particular sample is determined by 
Table 1 Forward $(\mathrm{F})$ and reverse $(\mathrm{R})$ primer sequences and amplification product length to measure gene expression by real-time RT-PCR or sequencing

\begin{tabular}{|c|c|c|}
\hline & Sequence $\left(5^{\prime} \rightarrow 3^{\prime}\right)$ & Length $(b p)$ \\
\hline \multicolumn{3}{|c|}{ For quantification } \\
\hline $\mathrm{GH}-\mathrm{F}$ & CTACAAAGAGTTCGAGCGTGCCTAC & 142 \\
\hline $\mathrm{GH}-\mathrm{R}$ & CAATTCCATGTCGGTTCTCTGCT & \\
\hline IGF-I-F & GTGTGGACCGAGGGGCTTTTACTTC & 146 \\
\hline IGF-I-R & GCTTCAGTGGGGCACAGTACATCTC & \\
\hline GHR-F & GATTTTACCCCCAGTCCCAGTTC & 198 \\
\hline GHR-R & GACССТTCAGTСТTСТСАТССАСА & \\
\hline ALS-F & ACCTGGACCGCAACCTCATC & 124 \\
\hline ALS-R & AGGCCAGGGAAGGTGTCCTC & \\
\hline \multicolumn{3}{|c|}{ For sequencing } \\
\hline GHseq-F & TCCTGTGGACAGATCACTGC & 642 \\
\hline GHseq-R & ACTTCATGACCCGCAGGTAG & \\
\hline GHRL1-F & TCTAGAACAGCCAGGGCTACA & 497 \\
\hline GHRL1-R & ATTTCTTGGTGCGTCTTGGT & \\
\hline GHRL2-F & GGTACCGAAGTCTCCCGCAACTACCA & 1296 \\
\hline GHRL2-R & TACTCACCCCAGTTCATGGAG & \\
\hline GHRseq1-F & AGGCGAAACTCCGAGGTCT & 504 \\
\hline GHRseq1-R & GGGTGGATCAGGTTGCACTA & \\
\hline GHRseq2-F & GAATGGAAAGAATGCССТGA & 689 \\
\hline GHRseq2-R & ATGGTGTTCAССТССТССАA & \\
\hline GHRseq3-F & TGCTGATTTTACССССАGTC & 570 \\
\hline GHRseq3-R & TTGCCAGTGATGTGGGATTA & \\
\hline GHRseq4-F & AACAAGCCACAGCCACTTTT & 648 \\
\hline GHRseq4-R & TCATGСТСТСССААСАСАGА & \\
\hline IGF1 seq-F & GATACACATCATGTCGTCTTCACA & 580 \\
\hline IGF1seq-R & GGGAAATGCCCATCTTTGTA & \\
\hline IGF1P1-1-F & GGCAACTAGGACAAGGGTCA & 460 \\
\hline IGF1P1-1-R & ТСТСТСССТСТTСТGGСАAA & \\
\hline IGF1P1-2-F & ATCTCCAGGAAGCACAATGC & 411 \\
\hline IGF1P1-2-R & TGCATGCACACATACACACA & \\
\hline IGF1P1-3-F & TCTGGCTCATTTCCATCTCC & 460 \\
\hline IGF1P1-3-R & CCСGTTGGCTGTATTGTTCT & \\
\hline p1 & GCCAGCTGGTATTATTTGGAA & 157 \\
\hline p2 & CCCGTTGGCTGTATTGTTCT & \\
\hline p3 & TCGСТСТTAAAAACTGGAGCA & 148 \\
\hline p4 & ССТTCAAACССTGTGGAAAG & \\
\hline HS 7-F & TTGAAGTCGCTCACCTTAGGG & 257 \\
\hline HS 7-R & ATTCTCTGGGAAGCACTCACGG & \\
\hline
\end{tabular}

interpolation from a standard curve of $\mathrm{Ct}$ values generated from the plasmid dilution series. The $18 \mathrm{~S}$ ribosomal RNA (rRNA) was used as a housekeeping gene.

\section{Gene analysis}

Total DNA was isolated from liver or kidney of mice using a DNeasy Tissue Kit (Qiagen) according to the manufacturer's instruction. The $\mathrm{P} 1$ promoter region and the GH-responsive element in intron 2 of the IGF-I gene (HS 7) (Woelfle et al. 2003), and the L1 and L2 promoters including the downstream region of the GHR gene were amplified with primer pairs listed in Table 1. For analysis of the coding region of GH, GHR and IGF-I gene, RT-PCR was performed with total RNA from pituitary or liver as a template. Platinum Pfx DNA polymerase (Invitrogen, Carlsbad, CA, USA) or proof reading Taq polymerase (Clontech, Palo Alto, CA, USA) was used for PCR to obtain results with high-fidelity. Sequence analysis was performed using a DNA sequencer (Model 3100; Applied Biosystems, Foster, CA, USA).

\section{Statistical analysis}

Results of gene expression were corrected for 18S rRNA amplified and are presented as means \pm S.E. Differences were determined by an unpaired $t$-test and coefficients of linear correlation (Pearson's) were calculated using GraphPad Prism version 4.00 for Windows (GraphPad Software, Inc., San Diego, CA, USA). Differences of allelic frequencies were determined by a chi-square test using GraphPad Quickcalcs software (GraphPad Software Inc). $P<0 \cdot 05$ was considered significant. 


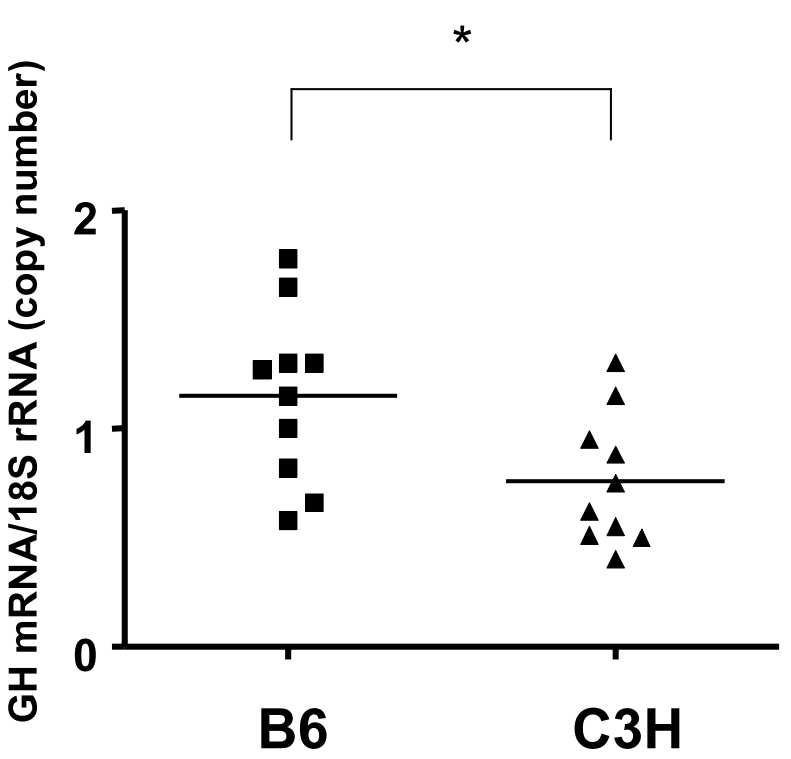

Figure 1 The levels of $\mathrm{GH}$ mRNA in pituitary gland in individual $\mathrm{B} 6$ and $\mathrm{C} 3 \mathrm{H}$ mice. $n=10$ for each strain. ${ }^{*} P<0 \cdot 05$.

\section{Results}

In the pituitary gland, $\mathrm{GH}$ mRNA levels of $\mathrm{C} 3 \mathrm{H}$ were $66 \%$ of those of B6 mice $(P=0 \cdot 02 ; n=10$ for each strain) (Fig. 1). Serum IGF-I levels in $\mathrm{C} 3 \mathrm{H}$ were $609 \cdot 3 \pm 16 \cdot 0 \mathrm{ng} / \mathrm{ml}$ whereas those in B6 were $455 \pm 14 \cdot 0 \mathrm{ng} / \mathrm{ml} \quad(P<0 \cdot 001)$. Hepatic IGF-I mRNA levels of $\mathrm{C} 3 \mathrm{H}$ were $146 \%$ of those of $\mathrm{B} 6(P=0 \cdot 01 ; n=10$ for each strain). Hepatic ALS mRNA levels of $\mathrm{C} 3 \mathrm{H}$ were $249 \%$ of B6 $(P<0 \cdot 005 ; n=10$ for each strain). Hepatic GHR mRNA levels of $\mathrm{C} 3 \mathrm{H}$ were $148 \%$ of those of $\mathrm{B} 6$ $(P=0 \cdot 03 ; n=10$ for each strain) (Fig. 2).

The correlations between hepatic IGF-I and pituitary GH, between hepatic IGF-I and ALS and between hepatic IGF-I and GHR mRNA in the two strains were examined. There was an inverse correlation between pituitary GH and hepatic IGF-I mRNA (Fig. 3a). There was a significant linear correlation between hepatic IGF-I and ALS mRNA (Fig. 3b) in both strains. There was also a significant correlation between hepatic IGF-I and GHR mRNA (Fig. 3c), consistent with our previous report (Iida et al. 2004a). In contrast in skeletal muscle, IGF-I mRNA levels of $\mathrm{C} 3 \mathrm{H}$ were comparable with those of $\mathrm{B} 6(n=10$ for each strain). GHR mRNA levels of $\mathrm{C} 3 \mathrm{H}$ were comparable with those of $\mathrm{B} 6$ as well $(n=10$ for each strain). There was no significant correlation between IGF-I and GHR mRNA in skeletal muscle (Fig. 4).

From the results of gene expression of hepatic IGF-I as well as ALS mRNA, we conclude that B6 is characterized by reduced $\mathrm{GH}$ action in liver despite having a greater expression of pituitary $\mathrm{GH}$ mRNA compared with $\mathrm{C} 3 \mathrm{H}$. Reduced mRNA levels of GHR in B6 suggest that reduced hepatic $\mathrm{GH}$ action in B6 may be at least in part
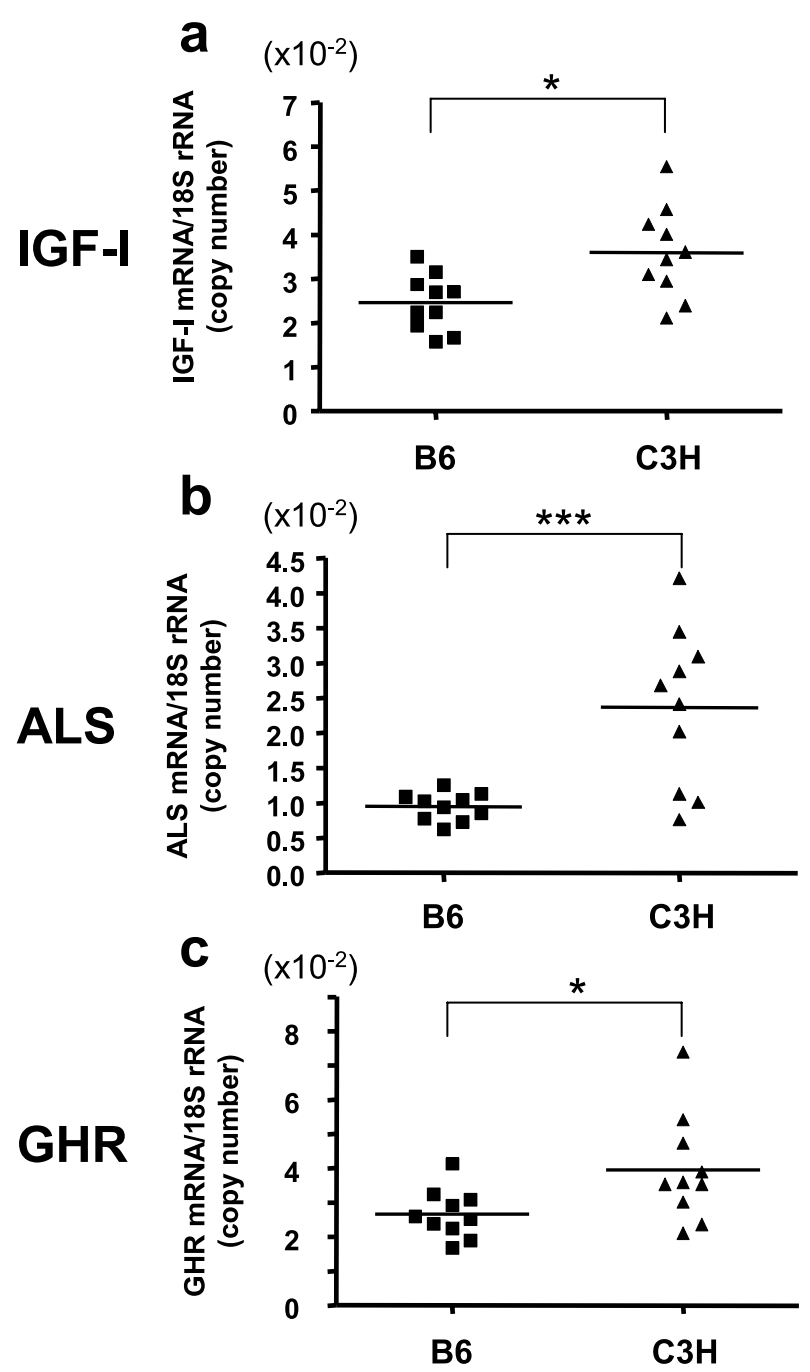

Figure 2 The levels of hepatic IGF-I (a), ALS (b) and GHR (c) mRNAs in individual $\mathrm{B} 6$ and $\mathrm{C} 3 \mathrm{H}$ mice. $n=10$ for each strain. ${ }^{*} P<0 \cdot 05,{ }^{* * *} P<0 \cdot 005$.

due to the down-regulation of the expression of GHR gene. Therefore, we next examined the genetic differences in the GHR as well as IGF-I genes including promoters, GH-responsive elements (HS 7), and proteincoding regions between the two strains. We also examined the protein-coding region of the $\mathrm{GH}$ gene to exclude the possibility of bioinactive $\mathrm{GH}$ in $\mathrm{B} 6$.

We identified the GT SSR (GT-SSR) downstream of the L2 promoter of the GHR gene (Fig. 5, Table 2). In addition, we identified the polyguanine repeat polymorphisms (poly G-SSR) in the P1 promoter region of the IGF-I gene (Fig. 5, Table 2). The GT-SSR in the GHR gene, however, was not significantly different between B6 and $\mathrm{C} 3 \mathrm{H}$. On the other hand, the length of the poly G-SSR of the IGF-I gene was significantly longer in B6 than in $\mathrm{C} 3 \mathrm{H}(P<0 \cdot 0001)$ (Table 2$)$. No polymorphisms 

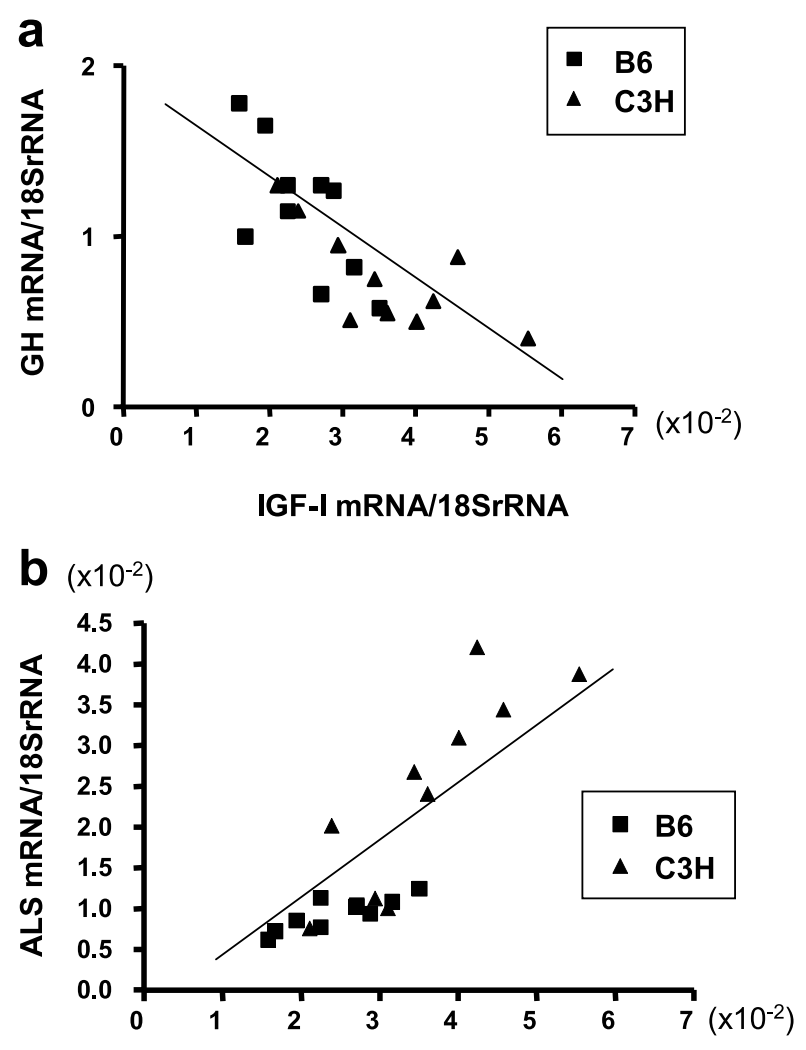

IGF-I mRNA/18SrRNA

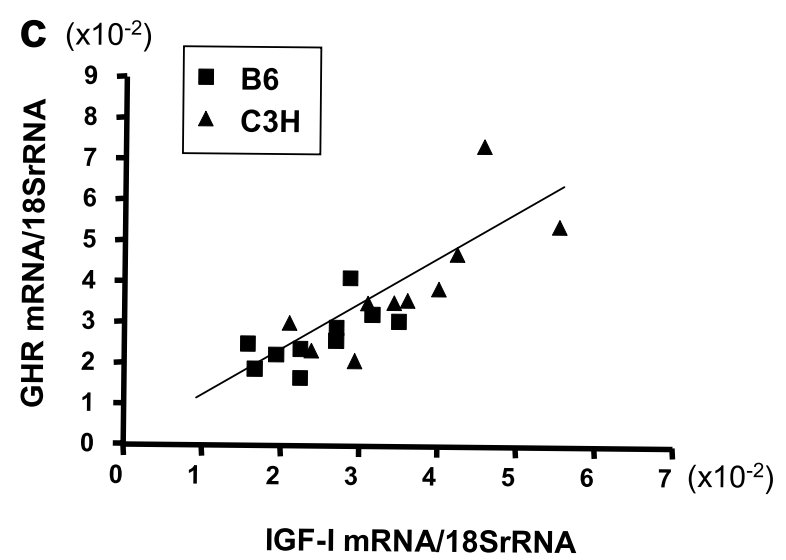

Figure 3 (a) There was a significant inverse correlation between hepatic IGF-I and pituitary GH mRNA in B6 $(r=-0 \cdot 7023$, $P=0.0235)$ and $\mathrm{C} 3 \mathrm{H}(r=-0.7301, P=0.0165)$. (b) There was a significant correlation between hepatic IGF-I and hepatic ALS mRNA in B6 $(r=0.8447, P=0.0021)$ and $\mathrm{C} 3 \mathrm{H}(r=0.8520$,

$P=0 \cdot 0017)$. (c) There was a significant correlation between hepatic IGF-I and hepatic GHR mRNA in B6 $(r=0.6676, P=0.0349)$ and $\mathrm{C} 3 \mathrm{H}(r=0 \cdot 7893, P=0 \cdot 0066)$.

were identified in either the protein-coding region or L1 promoter region of the GHR gene. No differences were observed in the protein-coding region or HS 7 of the IGF-I gene. Bioinactive GH in B6 was excluded as well.

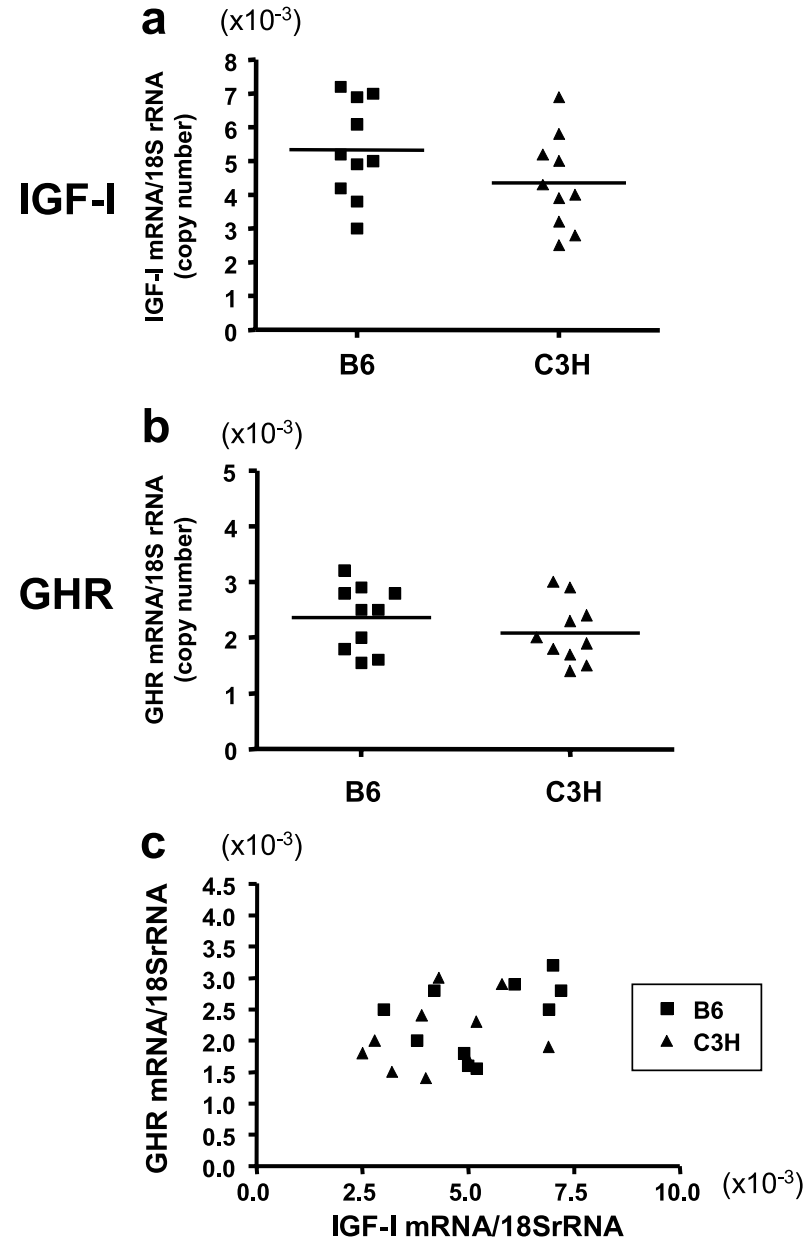

Figure 4 The levels of IGF-I (a) and GHR (b) mRNAs in skeletal muscle in individual $\mathrm{B} 6$ and $\mathrm{C} 3 \mathrm{H}$ mice. There was no significant difference between the two strains. $n=10$ for each strain. (c) There was no correlation between hepatic IGF-I and hepatic GHR mRNA in skeletal muscle.

\section{Discussion}

We identified the genetic differences in the promoter region of IGF-I gene between $\mathrm{B} 6$ and $\mathrm{C} 3 \mathrm{H}$ mice. In addition, we believe that this is the first report in terms of characterization of gene expressions involved in the $\mathrm{GH}-$ IGF-I axis between $\mathrm{B} 6$ and $\mathrm{C} 3 \mathrm{H}$. We also demonstrated that there were no differences of IGF-I and GHR mRNAs in skeletal muscle between the two strains in contrast to the observations in liver, suggesting the tissuespecific alteration of IGF-I and GHR gene expression in liver in mouse strains.

We first showed that B6 mice had significantly greater GH mRNA levels in the pituitary gland than observed in the $\mathrm{C} 3 \mathrm{H}$ strain (Fig. 1), whereas no difference was observed in single-point serum GH level (data not shown). We suggest that the greater $\mathrm{GH}$ mRNA in B6 compared 


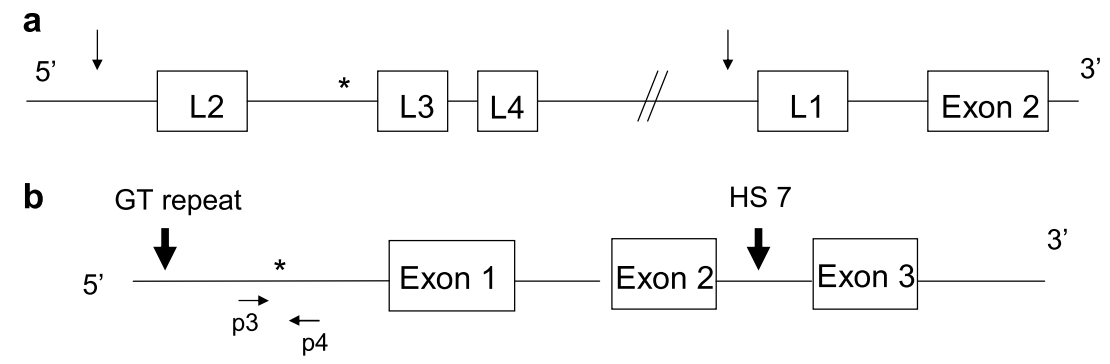

Figure 5 (a) Structure and the position of the GT-SSR in the mouse GHR gene. The asterisk denotes the position of the GT-SSR. The arrows denote the position of the L1 and L2 promoters. (b) Structure of mouse IGF-I P1 promoter and HS 7, and positions of primers we used to analyze the poly G-SSR. The asterisk denotes the position of poly G-SSR. GT repeat denotes the position corresponding to that identified in the human IGF-I gene, which is associated with serum IGF-I levels.

with $\mathrm{C} 3 \mathrm{H}$ pituitary reflects greater overall $\mathrm{GH}$ secretion in B6, because single-point serum measurement might not provide an accurate reflection of $\mathrm{GH}$ synthesis or release due to the pulsatile pattern of GH secretion. In this study, serum IGF-I level as well as hepatic IGF-I mRNA was significantly higher in $\mathrm{C} 3 \mathrm{H}$ than $\mathrm{B} 6$. As discussed below this probably reflects that hepatic IGF-I synthesis largely determines serum IGF-I; serum IGF-I is primarily responsible for negative feedback on GH synthesis and secretion. Thus, our results suggest that the phenotype of B6 is not due to insufficient $\mathrm{GH}$ synthesis.

Next, we examined the hepatic IGF-I, ALS and GHR mRNAs to clarify whether the reduced serum IGF-I level in B6 is GH-dependent or due to specific impairment of hepatic IGF-I synthesis per se. We used IGF-I and ALS mRNA levels as a marker of GH action, since both genes possess a STAT 5 binding element in the regulatory region and gene expression in both cases is regulated transcriptionally by GH (Ooi et al. 1998, Woelfle et al. 2003). The expression level of GHR is a critical factor in determining GH sensitivity in tissues. Our results demonstrated that IGF-I, ALS and GHR mRNA levels in liver were significantly reduced in $\mathrm{B} 6$ compared with $\mathrm{C} 3 \mathrm{H}$. Furthermore, we identified a significant correlation between hepatic IGF-I and ALS and between hepatic IGF-I and

Table 2 Allelic frequencies of the single sequence repeat (SSR) in the GHR and IGF-I genes

\section{GT-SSR in GHR gene}

\begin{tabular}{|c|c|c|c|c|c|}
\hline $\begin{array}{l}\text { Length } \\
\text { (bp) }\end{array}$ & B6 (n) & $\mathrm{C} 3 \mathrm{H}(n)$ & $\begin{array}{l}\text { Repeat } \\
\text { number }\end{array}$ & B6 (n) & $\mathrm{C} 3 \mathrm{H}(n)$ \\
\hline 74 & 6 & 5 & 15 & 2 & 0 \\
\hline 72 & 1 & 1 & 14 & 8 & 0 \\
\hline 70 & 1 & 2 & 10 & 0 & 9 \\
\hline 68 & 2 & 1 & 9 & 0 & 1 \\
\hline 66 & 0 & 1 & - & - & - \\
\hline
\end{tabular}

${ }^{* * *} P<0.0001$ between $\mathrm{B} 6$ and $\mathrm{C} 3 \mathrm{H}$.
GHR mRNA levels in individual mice of both B6 and $\mathrm{C} 3 \mathrm{H}$ strains. Taken together, our results suggest that low serum IGF-I levels in $\mathrm{B} 6$ compared with $\mathrm{C} 3 \mathrm{H}$ are, at least in part, due to reduced $\mathrm{GH}$ action in the liver.

$\mathrm{GH}$, rather than IGF-I, is the major regulator of liver growth (Behringer et al. 1990). The previous report demonstrated that GH-deficient little mice with the background of $\mathrm{C} 3 \mathrm{H}$ showed comparable susceptibility to hepatocarcinogenesis compared with those with a B6 background; these results contrast with those in wild-type, $\mathrm{GH}$-sufficient, $\mathrm{C} 3 \mathrm{H}$ mice, which were significantly more susceptible compared with B6 (Bugni et al. 2001). These results support reduced hepatic $\mathrm{GH}$ action in $\mathrm{B} 6$ mice.

The finding of reduced GHR mRNA levels in B6 led us to assume that low hepatic GHR expression might be responsible for hepatic $\mathrm{GH}$ resistance in $\mathrm{B} 6$. We therefore examined the sequence differences of GHR as well as IGF-I genes including the protein-coding, the GHresponsive element, and the $5^{\prime}$ flanking regions after excluding the possibility of bioinactive $\mathrm{GH}$ in $\mathrm{B} 6$ by sequencing. We detected no sequence differences between $\mathrm{B} 6$ and $\mathrm{C} 3 \mathrm{H}$ in the protein-coding region of the GHR. We identified a GT-SSR downstream of the L2 promoter region of the GHR gene (Table 2), which can act as an enhancer of transcription. There are several distinct $5^{\prime}$ untranslated region (exon 1) variants in mouse (L1-L5) as well as human GHR (V1-V9), and expression of each transcript is regulated by a different promoter (Edens \& Talamantes 1998, Menon et al. 2001). Several polymorphisms in the promoter region of GHR gene were reported in species including humans (Hadjiyannakis et al. 2001), Angus steers (Hale et al. 2000) and Angus cattle (Ge et al. 2003), although hitherto there has been no report in mice. Interestingly, the polymorphisms in humans located at $87 \mathrm{bp}$ upstream of V9 (Hadjiyannakis et al. 2001), homologous to mouse L3, correspond to those we found in mice. On the other hand, the polymorphisms identified in Angus steers or Angus cattle are located at the liver-specific promoter region, which is homologous to 
mouse L1; we found no sequence differences between B6 and $\mathrm{C} 3 \mathrm{H}$ in this region. Although we identified GT-SSR in the GHR gene in mice, there were no significant differences between $\mathrm{B} 6$ and $\mathrm{C} 3 \mathrm{H}$. Therefore, it is unlikely that this GT-SSR is the exclusive determinant of hepatic GHR expression between $\mathrm{B} 6$ and $\mathrm{C} 3 \mathrm{H}$. It is unclear why the hepatic expression of GHR in B6 was reduced compared with $\mathrm{C} 3 \mathrm{H}$. Since we searched a limited region of the whole GHR gene, it is possible that other unidentified polymorphisms may play a role in regulating hepatic GHR expression. Our previous report showed that there is a significant correlation between hepatic IGF-I and GHR mRNA levels in bovine GH transgenic and GH-deficient lit/lit mice (Iida et al. 2004a), consistent with the results in this study.

In the IGF-I gene, we also identified poly G-SSR in the P1 promoter region. Importantly, we could not detect any differences either in the GT-SSR in the P1 promoter, where polymorphisms were identified in humans (Rosen et al. 1998), or in the HS 7 region, which Woefle et al. (2003) pointed out as a critical regulatory region of IGF-I gene expression. On the other hand, the length of poly G-SSR was significantly longer in $\mathrm{B} 6$ than in $\mathrm{C} 3 \mathrm{H}$. This region corresponds to an E2F binding sequences. Li \& Baserga (1996) reported that the IGF-I promoter is constitutively active when the E2F binding sequence in the IGF-I promoter is mutated, suggesting the importance of this region for regulating IGF-I gene expression.

Besides the polymorphisms identified in the GHR and IGF-I genes, however, it is possible that other genetic factors may affect the expression of hepatic IGF-I and GHR as well. In this regard, we previously identified chromosomal locations or quantitative trait loci (QTL) linked to serum IGF-I concentrations. The QTL that mapped to the largest effect on circulating IGF-I concentration is on chromosome (Chr) 6 , and the second largest one is on Chr 10, where murine IGF-I gene is located, whereas murine $\mathrm{GH}$ and GHR genes are mapped on $\mathrm{Chr}$ 11 and 15 respectively (Rosen et al. 2000).

Another relevant finding in this study is that expression patterns of IGF-I and GHR mRNAs differed between skeletal muscle and liver (Fig. 4). There was no correlation between IGF-I and GHR mRNA in skeletal muscle in contrast to the results in liver. This tissue-specific regulation of IGF-I and GHR mRNA is consistent with our recent report using GH-deficient lit/lit mice and bovine GH transgenic mice (Iida et al. 2004b). Our current results of tissue-specific regulation of IGF-I mRNA suggest that serum IGF-I concentration is not necessarily a surrogate of local IGF-I mRNA expression in all tissues. Serum IGF-I reflects primarily hepatic IGF-I synthesis. It acts to provide negative feedback to $\mathrm{GH}$ secretion.

LID or LI-IGF-I $-/$ - mice are a mouse model of selective knockout of hepatic IGF-I synthesis; these animals have a low serum IGF-I concentration (Sjogren et al. 1999, Yakar et al. 1999). Although LID and LI-IGF-I - / - mice show extremely low serum IGF-I levels, they have no resistance to $\mathrm{GH}$ in peripheral tissues and have high serum GH levels (Sjogren et al. 1999, Yakar et al. 1999, Wallenius et al. 2001). Furthermore, only a modest growth retardation was observed in LID mice despite their having an extremely low level of serum IGF-I (Yakar et al. 2002), suggesting that the serum IGF-I level is not a critical determinant of body growth. Therefore, it is not surprising that the body weight and height of $\mathrm{B} 6$ and $\mathrm{C} 3 \mathrm{H}$ are identical, despite having different levels of serum IGF-I (Rosen et al. 1997). Interestingly, LID mice demonstrated muscle insulin resistance with high serum insulin concentration (Yakar et al. 2001), hypercholesterolemia (Sjogren et al. 2001) and reduced cortical periosteal bone growth (Sjogren et al. 2002). Taken together, serum IGF-I level may play a relevant role in determining normal glucose, lipid and bone metabolisms rather than body growth, consistent with the phenotype between $\mathrm{B} 6$ and $\mathrm{C} 3 \mathrm{H}$. Inhibition of $\mathrm{GH}$ action improved insulin sensitivity in LID mice (Yakar et al. 2004), suggesting that increased GHR signaling in skeletal muscle plays a critical role in reducing insulin action. Our results in this study showed that B6 demonstrated relatively low GHR mRNA levels in liver, but the opposite trend was observed in skeletal muscle. The relatively increased GH action in skeletal muscle may be one of the explanations for the susceptibility to the development of diabetes in B6 compared with C3H (Kaku et al. 1989). Normal GHR and IGF-I receptor signaling in skeletal muscle may also explain the normal growth in $\mathrm{B} 6$ compared with $\mathrm{C} 3 \mathrm{H}$. The mechanism underlying the differences of gene expression of IGF-I and GHR between liver and skeletal muscle despite having the identical polymorphism between tissues is unclear. The use of different promoters of genes may regulate gene expression in a tissue-specific manner (Moffat et al. 2000). Alternatively, tissue-specific factors may contribute to the regulation of IGF-I and/or GHR expression. In this regard, Gowri et al. (2003) demonstrated that a repressosome complex at the $\mathrm{L} 2$ promoter of the GHR gene played a role in differential regulation of GHR between liver and kidney in insulinopenic diabetes resulting in down-regulation of GHR in liver but upregulation of GHR in kidney. Further studies are required to clarify the tissue-specific regulation of GHR as well as IGF-I between liver and skeletal muscle.

In conclusion, we have elucidated the profile of gene expressions of IGF-I and GHR in two inbred strains of mice with different serum IGF-I levels. The genetic differences between these inbred strains affected not only IGF-I but also GHR mRNA levels in a tissue-specific manner. We also identified the sequence differences in the $5^{\prime}$ flanking region of IGF-I gene in mice. Our results may in part account for the phenotypic differences between $\mathrm{C} 3 \mathrm{H}$ and $\mathrm{B} 6$ mice. 


\section{Acknowledgements}

We are grateful to Pattie Hellmann for her excellent technical assistance.

\section{Funding}

This work was supported in part by a grant from the Foundation for Growth Science in Japan, a grant from the Uehara Memorial Foundation (to K I), a grant from the NIH (AR 45433) (to C J R), and by grants from Bristol Myers Squibb and Pfizer and a gift to the laboratory by $\mathrm{Mr}$ Sal Ranieri (to M O T). The authors declare that there is no conflict of interest that would prejudice the impartiality of this scientific work.

\section{References}

Behringer RR, Lewin TM, Quaife CJ, Palmiter RD, Brinster RL \& D'Ercole AJ 1990 Expression of insulin-like growth factor I stimulates normal somatic growth in growth hormone-deficient transgenic mice. Endocrinology 127 1033-1040.

Bugni JM, Poole TM \& Drinkwater NR 2001 The little mutation suppresses DEN-induced hepatocarcinogenesis in mice and abrogates genetic and hormonal modulation of susceptibility. Carcinogenesis 22 1853-1862.

D'Ercole AJ, Stiles AD \& Underwood LE 1984 Tissue concentrations of somatomedin C: further evidence for multiple sites of synthesis and paracrine or autocrine mechanisms of action. PNAS $\mathbf{8 1}$ 935-939.

Domene HM, Bengolea SV, Martinez AS, Ropelato MG, Pennisi P, Scaglia P, Heinrich JJ \& Jasper HG 2004 Deficiency of the circulating insulin-like growth factor system associated with inactivation of the acid-labile subunit gene. New England Journal of Medicine 350 570-577.

Edens A \& Talamantes F 1998 Alternative processing of growth hormone receptor transcripts. Endocrine Reviews 19 559-582.

Ge W, Davis ME, Hines HC, Irvin KM \& Simmen RC 2003 Association of single nucleotide polymorphisms in the growth hormone and growth hormone receptor genes with blood serum insulin-like growth factor I concentration and growth traits in Angus cattle. Journal of Animal Science 81 641-648.

Giovannucci E 1999 Insulin-like growth factor-I and binding protein-3 and risk of cancer. Hormone Research 51 (Suppl 3) 34-41.

Gowri PM, Yu JH, Shaufl A, Sperling MA \& Menon RK 2003 Recruitment of a repressosome complex at the growth hormone receptor promoter and its potential role in diabetic nephropathy. Molecular and Cellular Biology 23 815-825.

Hadjiyannakis S, Zheng H, Hendy GN \& Goodyer CG 2001 GT repeat polymorphism in the $5^{\prime}$ flanking region of the human growth hormone receptor gene. Molecular and Cellular Probes 15 239-242.

Hale CS, Herring WO, Shibuya H, Lucy MC, Lubahn DB, Keisler DH \& Johnson GS 2000 Decreased growth in angus steers with a short TG-microsatellite allele in the P1 promoter of the growth hormone receptor gene. Journal of Animal Science 78 2099-2104.

Harrela M, Koistinen H, Kaprio J, Lehtovirta M, Tuomilehto J, Eriksson J, Toivanen L, Koskenvuo M, Leinonen P, Koistinen R et al. 1996 Genetic and environmental components of interindividual variation in circulating levels of IGF-I, IGF-II, IGFBP-1, and IGFBP-3. Journal of Clinical Investigation 98 2612-2615.
Iida K, Del Rincon JP, Kim DS, Itoh E, Nass R, Coschigano KT, Kopchick JJ \& Thorner MO 2004a Tissue-specific regulation of growth hormone $(\mathrm{GH})$ receptor and insulin-like growth factor-I gene expression in the pituitary and liver of GH-deficient (lit/lit) mice and transgenic mice that overexpress bovine $\mathrm{GH}(\mathrm{bGH})$ or a bGH antagonist. Endocrinology 145 1564-1570.

Iida K, Del Rincon JP, Kim DS, Itoh E, Coschigano KT, Kopchick JJ \& Thorner MO 2004b Regulation of full-length and truncated growth hormone $(\mathrm{GH})$ receptor by $\mathrm{GH}$ in tissues of lit/lit or bovine GH transgenic mice. American Journal of Physiology-Endocrinology and Metabolism 287 E566-E573.

Ishida BY, Blanche PJ, Nichols AV, Yashar M \& Paigen B 1991 Effects of atherogenic diet consumption on lipoproteins in mouse strains C57BL/6 and C3H. Journal of Lipid Research 32 559-568.

Kaku K, McGill J, Province M \& Permutt MA 1989 A single major gene controls most of the difference in susceptibility to streptozotocin-induced diabetes between $\mathrm{C} 57 \mathrm{BL} / 6 \mathrm{~J}$ and $\mathrm{C} 3 \mathrm{H} / \mathrm{HeJ}$ mice. Diabetologia 32 716-723.

Kao PC, Matheny AP Jr \& Lang CA 1994 Insulin-like growth factor-I comparisons in healthy twin children. Journal of Clinical Endocrinology and Metabolism 78 310-312.

Kayo T, Fujita H, Nozaki J, E X \& Koizumi A 2000 Identification of two chromosomal loci determining glucose intolerance in a C57BL/6 mouse strain. Comparative Medicine 50 296-302.

Kofoed EM, Hwa V, Little B, Woods KA, Buckway CK, Tsubaki J, Pratt KL, Bezrodnik L, Jasper H, Tepper A et al. 2003 Growth hormone insensitivity associated with a STAT5b mutation. New England Journal of Medicine 349 1139-1147.

Langlois JA, Rosen CJ, Visser M, Hannan MT, Harris T, Wilson PW \& Kiel DP 1998 Association between insulin-like growth factor I and bone mineral density in older women and men: the Framingham Heart Study. Journal of Clinical Endocrinology and Metabolism 83 4257-4262.

Laron Z 2004 Laron syndrome (primary growth hormone resistance or insensitivity): the personal experience 1958-2003. Journal of Clinical Endocrinology and Metabolism 89 1031-1044.

Li S \& Baserga R 1996 Epidermal growth factor and platelet-derived growth factor regulate the activity of the insulin-like growth factor I gene promoter. Experimental Gerontology 31 195-206.

Menon RK, Shaufl A, Yu JH, Stephan DA \& Friday RP 2001 Identification and characterization of a novel transcript of the murine growth hormone receptor gene exhibiting developmentand tissue-specific expression. Molecular and Cellular Endocrinology 172 135-146.

Moffat JG, Dao H \& Talamantes F 2000 Alternative 5'-untranslated regions of mouse $\mathrm{GH}$ receptor/binding protein messenger RNA are derived from sequences adjacent to the major L2 promoter. Journal of Endocrinology 167 145-152.

Ooi GT, Hurst KR, Poy MN, Rechler MM \& Boisclair YR 1998 Binding of STAT5a and STAT5b to a single element resembling a gamma-interferon-activated sequence mediates the growth hormone induction of the mouse acid-labile subunit promoter in liver cells. Molecular Endocrinology 12 675-687.

Platz EA, Pollak MN, Rimm EB, Majeed N, Tao Y, Willett WC \& Giovannucci E 1999 Racial variation in insulin-like growth factor-1 and binding protein-3 concentrations in middle-aged men. Cancer Epidemiology, Biomarkers and Prevention 8 1107-1110.

Procter AM, Phillips JA III \& Cooper DN 1998 The molecular genetics of growth hormone deficiency. Human Genetics 103 255-272.

Rosen CJ, Dimai HP, Vereault D, Donahue LR, Beamer WG, Farley J, Linkhart S, Linkhart T, Mohan S \& Baylink DJ 1997 Circulating and skeletal insulin-like growth factor-I (IGF-I) concentrations in two inbred strains of mice with different bone mineral densities. Bone 21 217-223.

Rosen CJ, Kurland ES, Vereault D, Adler RA, Rackoff PJ, Craig WY, Witte S, Rogers J \& Bilezikian JP 1998 Association between serum insulin growth factor-I (IGF-I) and a simple sequence repeat 
in IGF-I gene: implications for genetic studies of bone mineral density. Journal of Clinical Endocrinology and Metabolism $\mathbf{8 3}$ 2286-2290.

Rosen CJ, Churchill GA, Donahue LR, Shultz KL, Burgess JK, Powell DR, Ackert C \& Beamer WG 2000 Mapping quantitative trait loci for serum insulin-like growth factor-1 levels in mice. Bone 27 521-528.

Sandhu MS, Heald AH, Gibson JM, Cruickshank JK, Dunger DB \& Wareham NJ 2002 Circulating concentrations of insulin-like growth factor-I and development of glucose intolerance: a prospective observational study. Lancet 359 1740-1745.

Shi W, Wang NJ, Shih DM, Sun VZ, Wang X \& Lusis AJ 2000 Determinants of atherosclerosis susceptibility in the $\mathrm{C} 3 \mathrm{H}$ and C57BL/6 mouse model: evidence for involvement of endothelial cells but not blood cells or cholesterol metabolism. Circulation Research 86 1078-1084.

Sjogren K, Liu JL, Blad K, Skrtic S, Vidal O, Wallenius V, LeRoith D, Tornell J, Isaksson OG, Jansson JO et al. 1999 Liver-derived insulin-like growth factor I (IGF-I) is the principal source of IGF-I in blood but is not required for postnatal body growth in mice. PNAS 96 7088-7092.

Sjogren K, Wallenius K, Liu JL, Bohlooly YM, Pacini G, Svensson L, Tornell J, Isaksson OG, Ahren B, Jansson JO et al. 2001 Liver-derived IGF-I is of importance for normal carbohydrate and lipid metabolism. Diabetes 50 1539-1545.

Sjogren K, Sheng M, Moverare S, Liu JL, Wallenius K, Tornell J, Isaksson O, Jansson JO, Mohan S \& Ohlsson C 2002 Effects of liver-derived insulin-like growth factor I on bone metabolism in mice. Journal of Bone and Mineral Research 17 1977-1987.

Stewart CE \& Rotwein P 1996 Growth, differentiation, and survival: multiple physiological functions for insulin-like growth factors. Physiological Reviews 76 1005-1026.

Takahashi Y, Kaji H, Okimura Y, Goji K, Abe H \& Chihara K 1996 Short stature caused by a mutant growth hormone. New England Journal of Medicine 334 432-436.

Takahashi Y, Shirono H, Arisaka O, Takahashi K, Yagi T, Koga J, Kaji H, Okimura Y, Abe H, Tanaka T et al. 1997 Biologically inactive growth hormone caused by an amino acid substitution. Journal of Clinical Investigation 100 1159-1165.

Wallenius K, Sjogren K, Peng XD, Park S, Wallenius V, Liu JL, Umaerus M, Wennbo H, Isaksson O, Frohman L et al. 2001 Liver-derived IGF-I regulates GH secretion at the pituitary level in mice. Endocrinology 142 4762-4770.

Woelfle J, Chia DJ \& Rotwein P 2003 Mechanisms of growth hormone $(\mathrm{GH})$ action. Identification of conserved Stat5 binding sites that mediate GH-induced insulin-like growth factor-I gene activation. Journal of Biological Chemistry 278 51261-51266.

Woods KA, Camacho-Hubner C, Savage MO \& Clark AJ 1996 Intrauterine growth retardation and postnatal growth failure associated with deletion of the insulin-like growth factor I gene. New England Journal of Medicine 335 1363-1367.

Yakar S, Liu JL, Stannard B, Butler A, Accili D, Sauer B \& LeRoith D 1999 Normal growth and development in the absence of hepatic insulin-like growth factor I. PNAS 96 7324-7329.

Yakar S, Liu JL, Fernandez AM, Wu Y, Schally AV, Frystyk J, Chernausek SD, Mejia W \& Le Roith D 2001 Liver-specific IGF-1 gene deletion leads to muscle insulin insensitivity. Diabetes $501110-1118$.

Yakar S, Rosen CJ, Beamer WG, Ackert-Bicknell CL, Wu Y, Liu JL, Ooi GT, Setser J, Frystyk J, Boisclair YR et al. 2002 Circulating levels of IGF-I directly regulate bone growth and density. Journal of Clinical Investigation 110 771-781.

Yakar S, Setser J, Zhao H, Stannard B, Haluzik M, Glatt V, Bouxsein ML, Kopchick JJ \& LeRoith D 2004 Inhibition of growth hormone action improves insulin sensitivity in liver IGF-1-deficient mice. Journal of Clinical Investigation 113 96-105.

Yoshie M, Nishimori H, Lee GH \& Ogawa K 1998 High colony forming capacity of primary cultured hepatocytes as a dominant trait in hepatocarcinogenesis-susceptible and resistant mouse strains. Carcinogenesis 19 1103-1107.

Received 9 May 2005

Accepted 20 June 2005 